\title{
The Effectiveness of Task-Based Language Teaching in Developing Speaking Skills at SMKN 2 MALANG
}

\author{
Tities Hijratur Rahmah \\ Program Studi Pendidikan Bahasa Inggris \\ IKIP Budi Utomo Malang \\ Jalan Simpang Arjuno 14-B Malang
}

\begin{abstract}
In this study the researcher proposed using a procedure based on the use of tasks as the core unit of planning and instruction in language teaching called Task-Based language Teaching (TBLT) to enhance the speaking ability of EFL learners. The present study was focused on seeing whether the TaskBased Language Teaching more effective to develop the students' achievement in speaking. In this study the researcher used the population of the tenth grade students of SMKN 2 Malang in 20014/20015 academic year. In conducting this research, the researcher used the quasi-experimental design in terms of using one experimental group and one control group. These groups were chosen randomly from tenth grade classes from the two classes. The result of this study shows that there is a significant difference in the scores for Task-Based Language Teaching method and Audio lingual method after controlling for scores on the test. From the ANCOVA computation, it can be concluded that the students in experimental group had better achievement than those in control group.
\end{abstract}

Keywords: Effectiveness, Task-Based Language Teaching, Speaking Skills.

English has attained increasing importance throughout the world in general and in Indonesia in particular. Consequently, indonesion parents and educators have begun to be concerned about their children's low level in English, and have begun to look for solutions to this problem. More and more pupils have extensive contact with English before beginning formal English instruction or outside of school, whether through radio, television, computers, family, travel, or meeting oversees visitors. Most pupils, at whatever age they start English in school, have already learned words and phrases of the language. Curriculum designers set new standards for English while taking these standards into consideration. The new standards are extremely flexible, and offer schools and teachers freedom to determine the appropriate methodology to be used and the priority of the elements of the curriculum (Amara and Marai, 2002).

Speaking is an interactive process of constructing meaning that involves producing, receiving and processing information. Today, the new curriculum focuses on speaking skills through the domain of social interaction. This is because speaking skills are extremely important when teaching EFL. The importance of teaching speaking skills stems from the fact that human beings have been acquiring language through speaking and listening long before they began reading and writing. Our brains are well programmed to learn language through sound and speech.

The purpose of this study was to answer directly the main research problem," Do the students who were taught by Task Based Language Teaching have better achievement in speaking than those who were taught by Audio lingual method? The present study was focused on seeing whether the Task-Based Language Teaching more effective to develop the students' achievement in speaking.

\section{METHOD}

The current study adopted the quasiexperimental design in terms of using one experimental group and one control group. These groups were chosen randomly from tenth grade classes from the two classes.

The population of the study was the tenth gradestudents of SMKN2Malang in 20014/20015 academic year. As there are 90 students, this research doesn't use sampling procedure. Those 
90 students were used as the experimental group and control group as well. The students were separated randomly and it resulted 45 students as control group and 45 students as experimental group. Before the experiment was done, the pretest was administered to those two groups. After having the result of the test, the treatment was begun. The experimental group was taught by using Task-Based Language Teaching and the control group was taught by using conventional technique. This treatment spent 3 months February 21, 2015 until the second week of May 2015. At the end of the treatment, the posttest was administered to see the effect of the two techniques to the students' Speaking Skills. To achieve the purpose of the present study, the data were analyzed by using Pearson correlation and ANCOVA analyses with the help of SPSS 16.

\section{FINDINGS}

The researcher calculated the means, the standard deviations of the adjusted means and the standard error of the students' scores on the pre and post-test according to the teaching procedure. The results are presented in Table 4.1
Table 4.2 shows that there are observed differences between the adjusted means of both groups according to the teaching procedure in post test score. It shown that the means for experimental group in post test is 76.65 , and the means for controlling group in post test is 72.73 .

The comparison between first rater and second rater could be detected by using correlation test to find the result of reliability between two raters.

Table 4.3 The result of Inter Rater Reliability.

Correlations

\begin{tabular}{llll}
\hline & & Rater 1 & Rater 2 \\
\hline Rater 1 & Pearson Correlation & 1 & $.882^{* *}$ \\
& Sig. (2-tailed) & & .000 \\
& $\mathrm{~N}$ & 45 & 45 \\
\hline Rater 2 & Pearson Correlation & $.882^{* *}$ & 1 \\
& Sig. (2-tailed) & .000 & \\
& $\mathrm{~N}$ & 45 & 45 \\
\hline
\end{tabular}

**. Correlation is significant at the 0.01 level (2-tailed).

Table 4.3 above shown that the inter rater reliability is 0,882 . It means that the reliability is

Table 4.1 Means, Standard Deviations, and Standard Errors of the Subjects' Scores on the Pre Tests According to the Teaching Procedure

\section{Group Statistics}

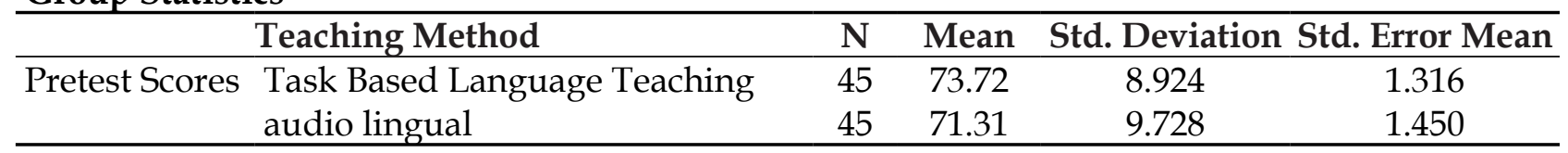

Table 4.1 shows that there are observed differences between the adjusted means of both groups according to the teaching procedure in pre test score. It shown that the means for experimental group in pre test is 73.72, and the means for controlling group in pre test is 71.31 . very high (very strong), because the coefficient is higher than 80 .

The researcher used ANCOVA to find the significance of these differences. The results are presented in Table 4.4

Table 4.2 Means, Standard Deviations, and Standard Errors of the Subjects' Scores on the Post Tests According to the Teaching Procedure

Group Statistics

\begin{tabular}{llcccc}
\hline & Teaching_Method & N & Mean & Std. Deviation & Std. Error Mean \\
\hline Posttest_Scores & Task Based Language Teaching & 45 & 76.65 & 7.376 & 1.088 \\
& audio lingual & 45 & 72.73 & 9.009 & 1.343 \\
\hline
\end{tabular}


Table 4.4 Results of ANCOVA on the Total Score of the Speaking Test Due to Teaching Procedure.

Tests of Between-Subjects Effects

Dependent Variable : Posttest Scores

\begin{tabular}{llcccccc}
\hline Source & & $\begin{array}{c}\text { Type III Sum } \\
\text { of Squares }\end{array}$ & Df & Mean Square & F & Sig. $\begin{array}{c}\text { Partial } \\
\text { Eta } \\
\text { Squared }\end{array}$ \\
\hline Intercept & Hypothesis & 252188.203 & 1 & 252188.203 & 705.004 & .000 & .989 \\
& Error & 2927.440 & 8.184 & $357.712^{\mathrm{a}}$ & & & \\
Teaching Method & Hypothesis & 50.814 & 1 & 50.814 & 6.315 & .019 & .203 \\
& Error & 199.300 & 24.769 & $8.046^{\mathrm{b}}$ & & & \\
Pretest Scores & Hypothesis & 4772.770 & 8 & 596.596 & 85.756 & .000 & .988 \\
& Error & 59.512 & 8.554 & $6.957^{\mathrm{c}}$ & & & \\
Teaching Method * & Hypothesis & 47.146 & 7 & 6.735 & .668 & .699 & .059 \\
Pretest Scores & Error & 746.581 & 74 & $10.089^{\mathrm{d}}$ & & & \\
\hline
\end{tabular}

a. MS (Prestest Scores) + .020 MS (Teaching Method * Prestest Scores) + .387 MS (Error)

b. MS (Teaching Method * Prestest Scores) +.391 MS (Error)

Table 4.4 shows that there is a statistically significant difference (0.05) between the two adjusted means of the students' scores on the post -test attributed to the teaching procedure in favor of the members of the experimental group. Based on this table the value is F $6.315(\mathrm{P}<.019)$, which is less than .05 ; therefore, the result is significant.

\section{DISCUSSION}

Based on the value F $6.315(p<.019)$ it indicated that there is a statistically significant difference (0.05) between the two adjusted means of the students' scores due to the teaching procedure in favor of the experimental group. The results can be explained by the fact that the TBLT program emphasized the fluency of the participants rather than the bits and pieces of the linguistic competence of the learners. In task based learning, the tasks are central to the learning activity. The method is based on belief that students can learn more effectively when their minds are focused on the task, rather than on the language they are using. Learning to speak and to understand the language automatically in a vast variety of situations requires intensive exposure to language and unlimited interaction with language users. Furthermore, TBLT enables the teachers to improve the students' communicative skills, to provide opportunities for native like interactions, to practice making oral representations immediately after getting enough meaning.

\section{CONCLUSION}

The findings reveal that Task-based language teaching (TBLT) improves students' speaking skill; the students' fluency and accuracy have improved significantly. It's caused of the teachers have planned the task well before entering the class. The students of vocational high school usually encounter problems in learning English and only a low percentage of them pass the English matriculation examination. This might be partially attributed to the lack of exposure to authentic English. TBLT can be the solution for this lack of exposure to authentic English; TBLT gives the students a chance to practice their English by using different activities in real world tasks and in a stress free atmosphere in the classroom setting. Through TBLT procedures, students have more time to discuss the task topic using their personal experiences either with other mates or with the teacher. 
56 | Tities Hijratur Rahmah, The Effectiveness of Task-Based Language ...

\section{REFERENCES}

Amara, M. and Marai, A. (2002). Language Education Policy. From,http://www. tc.columbia.edu/i/a/document/4254 SIEVolume3Languages.pdf.

Cunningham, F. M. (1999). English Language Learners' Speaking Skill. Eric Digest. Retrieved January, 15, 2009, from, http//:www.Eric.ed gov.

Ellis, R. (2003). Task-Based Language Learning and Teaching, from, http://tesl-ej.org/ej27/ r5.html.

Krashen, S. D. (1987). Principles and Practices in Second Language Acquisition.

New York: Prentice-Hall.Long, M.H., \& Crooks, G. (1991). Three approaches to taskbased syllabus design. TESOL Quarterly, 26(1), 27-56.
Mukminatien, N. (2005). Modul Pengembangan Asesmen Pembelajaran Bahasa. Malang: Universitas Negeri Malang (UM PRESS).

Nunan, D. (1996). Designing Tasks for the Communicative Classroom. Cambridge: Cambridge University Press.

Sutinah, Entinah.2002.Get Along With English For Vocational School Grade X. Malang: Penerbit Erlangga

Tin, T. B. (2003). Does Talking with Peers Help Learning? The Role of Expertise and Talk in Convergent Group Discussion Tasks. Journal of English for Academic Purposes 2.1. 53-66.

Willis, J. (1996). A Framework for Tasked-Based Learning.London: Longman. 